\title{
HYPOGENE POINT KARSTIFICATION ALONG WADI SIRHAN GRABEN (JORDAN): A SIGN OF OILFIELD DEGASSING?
}

\author{
ZAKRASEVANJE OB VADIJU SIRHAN GRABEN (JORDANIJA): \\ POSLEDICA RAZPLINJANJA NAFTNIH POLJ?
}

\author{
Ahmad AL-MALABEH ${ }^{1} \&$ Stephan KEMPE ${ }^{2}$
}

\begin{abstract}
UDC 551.435.84(569.5)

Ahmad Al-Malabeh \& Stephan Kempe: Hypogene Point Karstification along Wadi Sirhan Graben (Jordan): A Sign of Oilfield Degassing?

Jordan is a country with a large area of limestone. Nevertheless, only a few limestone caves are known. Here we report about two caves along Wadi Sirhan Graben of Jordan that appear to have formed by stoping upward of collapsed deep-seated hypogene cavities along breccia pipes. The first one, Uwaiyed Cave, is a small breakdown-dominated chamber in basalt of the Naslet Al-Dhirwa volcano; the second, Beer Al-Malabeh, is a large, bell-shaped sinkhole that has geologically recently opened up to the surface. We discuss the possible processes that led to their formation. The review of the existing stratigraphy as obtained by oil well drilling suggests that no salt layers occur below the caves. Gypsum layers seem to be limited to $4 \mathrm{~m}$ in thickness, probably not enough to form the observed features. The remaining process is dissolution caused by ascending gas ( $\mathrm{H} 2 \mathrm{~S}$ or $\mathrm{CH} 4)$-rich waters from the underlying oil and oilshale fields. When such solutions reach the water table, bacterial oxidation may create enough dissolutional power to form localized and large cavities. Their collapse could lead to the observed collapse structures and would explain the paucity of other cave structures throughout southeastern Jordan.

Keywords: Jordan, hypogene caves, sinkholes, oil fields, methane.
\end{abstract}

Izvleček UDK 551.435.84(569.5)
Ahmad Al-Malabeh \& Stephan Kempe: Zakrasevanje ob vadi-
ju Sirhan Graben (Jordanija): Posledica razplinjanja naftnih
polj? Čeprav je v Jordaniji veliko območje apnencev, je tam malo poznanih jam. V članku obravnavamo jame vzdolž vadija Sirhan Graben, ki so očitno nastale s podornim višanjem stropov hipogenih votlin. Jama Uwaiyed je majhna podorna dvorana v bazaltu vulkana Naslet Al-Dhirwa. Beer Al-Malabeh je velika udornica zvonaste oblike, ki se je verjetno geološko nedavno odprla na površje. $V$ članku obravnavamo procese nastanka teh jam. Stratigrafski podatki iz naftnih vrtin kažejo, da pod jamami ni solnih plasti, plasti sadre pa so debele do 4 $\mathrm{m}$, kar je verjetno premalo, da bi jih povezovali z nastankom opisanih jam. Kot možen proces ostane raztapljanje dvigajoče se vode obogatene $\mathrm{s}_{2} \mathrm{~S}$ ali $\mathrm{CH}_{4}$, ki izvirajo iz spodaj ležečih naftnih polj. $\mathrm{V}$ območju nivoja podtalnice lahko bakterijska oksidacija raztopin ustvari dovolj korozivnosti za nastanek velikih votlin. Na območju je znanih več podornih struktur, ki so lahko rezultat podiranja takih votlin. Prav tako pa je podiranje možen vzrok, da v jugovzhodni Jordaniji ni veliko drugih jamskih objektov.

Ključne besede: Jordanija, hipogene jame, udornice, naftna polja, metan.

\section{INTRODUCTION}

In Jordan features caused by karstic processes are particularly observed in the north where terra rossa occurs (e.g., Al-Malabeh 2000). These features include several limestone caves and shallow and deeper bowl-shaped depressions particularly in Al-Bwaidha Town south of Irbid. Dissolution holes of $1 \mathrm{~m}$ in diameter on average

\footnotetext{
${ }^{1}$ Hashemite University, Department of Earth and Environmental Sciences, P.O. Box 150459, Zarka 13115, Jordan, e-mail: Am@hu.edu.jo, a_malabeh@yahoo.com

${ }^{2}$ Inst. für Angewandte Geowissenschaften, Technische Universität Darmstadt, Schnittspahnstr. 9, D-64287 Darmstadt, Germany, e-mail: kempe@geo.tu-darmstadt.de
}

Received/Prejeto: 7.3.2011 
and depths of $0.2-3 \mathrm{~m}$ and subsurface collapse structures occur adjacent to the Yarmouk river canyon. Others are circular to subcircular depressions with diameters ranging from tens of meters up to several kilometres. Some reach depths of $20 \mathrm{~m}$ while others are only a few meters deep. The most distinctive karst areas occur near the villages of Samar, Hartha, Hubras, Aqraba and Al-Rafeed in the northern high lands of Jordan. Several large caves are also recorded in Kufranja and Rasoun-Ajloun Districts (Al-Malabeh et al. 2007). The only larger limestone cave yet discovered in Jordan is Al-Daher Cave at Bergish (Kempe et al. 2006a). But even in the limestone deserts of Jordan many depressions are known. The recent de- cline of the Dead Sea (e.g., Abu-Ghazleh et al. 2009) is diverting fresh groundwater into salt layers that were previously protected from dissolution by salt-saturated groundwater. These salt layers are now dissolving creating a substantial sinkhole hazard along both sides of the Dead Sea (Closson 2005; Arkin \& Gilat 2000).

Here we report about two caves, Uwaiyed Cave and Al-Malabeh Sinkhole (Kempe et al. 2009b), the first caves from the Harrat Al-Shaam and Wadi Sirhan Graben (Al-Malabeh 2007) which appear to have been created by hypogene processes and discuss the options for their genesis (see Fig. 1 for locations).

\section{CAVE DEVELOPMENT}

Karst has recently become a term difficult to define (e.g., Kempe 2008). Classically, "karst" is understood as a landscape type that is drained preferentially underground through secondarily developed caves. In this context we speak of a karstic aquifer that allows short-term passage of large volumes of water. These systems are mostly developed in limestone, dolomite or gypsum, rarely also in salt. The caves thus created are karstic caves sensustricto.

However, not all caves are created by this sort of water passage. First of all the primary caves, like lavatunnels (e.g., overview see Kempe 2002; in Jordan: AlMalabeh et al. 2006; Kempe et al. 2006b), do not fit this picture. But even a large number of caves in limestone or gypsum have not been created by the horizontal passage of water from the surface via subterraneous cavities to distant springs (a type of caves called sensu Klimchouk 2007, epigene caves) but by waters rising vertically from underlying aquifers either into more soluble rocks (limestone, gypsum, salt) (see for example some of the large anhydrite/gypsums caves discovered by mining in the South Harz/Germany, Kempe 1996a), or by acquiring additional solution power in higher levels (a deep phreatic type of caves called sensu Klimchouk 2007, hypogene caves) (see for example development of the famous caves in the Guadalupe Mountains New Mexico, e.g. Palmer 2008, or of Al-Daher Cave in Jordan, Kempe et al. 2006a). Thus hypogene karstic features can sporadically appear outside the area of widespread underground drainage systems. Often the only expression of such cavities are large sinkholes at the surface (such as for example in Saudi Arabia above the Upper Jurassic Heeth Formation, see Kempe \& Dirks 2008).

Understanding the hydrological pathways of cave formation is one aspect but the nature of the local un- dersaturation is another. In case of gypsum, water rising from a limestone aquifer can dissolve additionally gypsum/anhydrite, thus "eating" it away from underneath. In case of limestone $\left(\mathrm{CaCO}_{3}\right)$ dissolution we need however to understand how locally enough "dissolution capacity" (DC) arises, to create large caves. To estimate this, we need to know (i) local undersaturation $\left(\mathrm{C}_{\text {saturation }}-\mathrm{C}_{\text {actual }}\right.$, measured in mol $\mathrm{CaCO}_{3} \mathrm{~kg}^{-1}$ ) and (ii) the flux (F) of the protons $\left(\left[\mathrm{H}^{+}\right]\right.$) (measured in $\mathrm{mol} \mathrm{kg}^{-1} \mathrm{~s}^{-1}$ ) that produce and keep the local undersaturation of the percolating water:

$\mathrm{DC}=\mathrm{F}\left[\mathrm{H}^{+}\right]^{*}\left(\mathrm{C}_{\text {saturation }}-\mathrm{C}_{\text {actual }}\right)$

In nature, many processes can lead to local undersaturation and many different chemical pathways can be followed, generating protons to fuel carbonate dissolution. In most karst areas with longitudinally developed vadose or phreatic karst systems, $\mathrm{CO}_{2}$ (i.e. its pressure) plays the major role in generating dissolution capacity (for extensive reviews on karst genesis see Klimchouk et al. 2000):

$$
\begin{aligned}
& \mathrm{CO}_{2}+\mathrm{H}_{2} \mathrm{O} \rightarrow \mathrm{H}^{+}+\mathrm{HCO}_{3}^{-} \\
& \mathrm{H}^{+}+\mathrm{HCO}_{3}^{-}+\mathrm{CaCO}_{3} \rightarrow \mathrm{Ca}^{2+}+2 \mathrm{HCO}_{3}^{-}
\end{aligned}
$$

Undersaturation is either primary, i.e. the sinking creek or percolating seepage water is undersaturated with respect to limestone or it is secondary, i.e. it is acquired within the karstifyable rock (Kempe 1996b). Primary undersaturation is probably among the major factors, since the dissolution velocity in natural rocks changes at about $70 \%$ of saturation to higher order kinetics, i.e. dissolution rate becomes slower and slower as the thermodynamic saturation is approached. Thus, dissolution capacity can be carried far (i.e. many kilometers) into the rock strata (e.g., Dreybrodt 2008). For a long time it was thought that mixing corrosion was the 
major source of dissolution capacity (Bögli 1964). This term refers to the fact that the mixing of two waters in equilibrium with $\mathrm{CaCO}_{3}$ and the $\mathrm{PCO}_{2}$ (partial pressure of $\mathrm{CO}_{2}$ ) (i.e. at a $100 \%$ saturation) generates additional free $\mathrm{CO}_{2}$ that renders the mixture undersaturated again. This is possible because of the non-linearity of the $\mathrm{H}_{2} \mathrm{O}-\mathrm{CO}_{2}-\mathrm{CaCO}_{3}$ system (e.g., Wigley 1973; Wigley \& Plummer 1976). Mixing corrosion theoretically occurs in those cases where seepage waters flowing along different tectonic planes (joints, bedding planes, faults) mix at intersections. Possibly both effects play a certain role in karst genesis (Dreybrodt 2008).

However, this is only part of the story. In many areas we find huge cavities that do not connect to lateral karst systems. These caves seem to obtain their dissolution capacity from in situ processes. Several processes have been identified that could do that:

1) cooling of thermal waters (e.g., Dublyanski 2000);
2) rising of gaseous volcanic $\mathrm{CO}_{2}$ (e.g., Gary \& Sharp 2006);

3) in situ respiration of organic matter (decaying wood for example) following:

$\mathrm{C}_{6} \mathrm{H}_{12} \mathrm{O}_{6}+6 \mathrm{O}_{2}+6 \mathrm{H}_{2} \mathrm{O} \rightarrow 6 \mathrm{CO}_{2}+6 \mathrm{H}_{2} \mathrm{O}$;

4) oxidation of siderite by oxygen bearing groundwater to goethite following:

$4 \mathrm{FeCO}_{3}+\mathrm{H}_{2} \mathrm{O}+\mathrm{O}_{2} \rightarrow 4 \mathrm{CO}_{2}+2 \mathrm{Fe}_{2} \mathrm{O}_{3}{ }^{*} \mathrm{nH}_{2} \mathrm{O}(\mathrm{Kem}-$ pe 1975,2009 );

5) oxidation of methane $\left(\mathrm{CH}_{4}\right)$ by oxygen-bearing groundwater following:

$\mathrm{CH}_{4}+\mathrm{O}_{2} \rightarrow 4 \mathrm{H}^{+}+\mathrm{CO}_{2}$; (e.g., Kempe 1996c) and

6) oxidation of hydrogensulphide $\left(\mathrm{H}_{2} \mathrm{~S}\right)$ by oxygenbearing groundwater following:

$\mathrm{H}_{2} \mathrm{~S}+2 \mathrm{O}_{2} \rightarrow 2 \mathrm{H}^{+}+\mathrm{SO}_{4}^{2-} \rightarrow \mathrm{H}^{+}+\mathrm{HSO}_{4}^{2-}$ (e.g., Hill 2000; Palmer \& Palmer 2000).

\section{TECTONIC AND STRATIGRAPHIC SETTING}

\section{TECTONIC SETTING}

The tectonic setting of Jordan is closely related to the regional geology and tectonics of the Eastern Mediterranean area. Several intra-plate deformation phases affected the northern Arabian Plate between the Late Paleozoic and the Cenozoic (McKenzie et al. 1970; Gregory et al. 1982). Major rifting episodes occurred in the Late Carboniferous to Permian, Middle to Late Triassic, and at the end of the Early Cretaceous. Besides the major Dead Sea Transform Fault, the Wadi Sirhan Graben(WSG) is the second main regional structure in Jordan (Fig. 1). This graben belongs to the Erythrean Fault System: A structure that consists of NW-SE and E-W oriented normal and strike-slip faults from the Late Miocene to Early Pliocene (e.g., Barazangi 1983; Kazmin 2002). The WSG consists of fault systems more than $325 \mathrm{~km}$ long and extends from northwestern Saudi Arabia through Jordan up to the Antilebanon.

The Azraq Basin, located in the Jordan Plateau, is a tectonic depression associated with the WSG. The basin covers an area of about $12,220 \mathrm{~km}^{2}$ and is underlain by layers of limestone interbedded with marl, sand, chalk, chert, and sandstone that overlie granitic basement rocks. North of Azraq, the graben is covered by the basaltic plateau of Harrat Al-Shaam (e.g., Al-Malabeh 1994).

Bender (1974) concluded that the depression is the result of epirogenic subsidence without large scale faulting during the Cenozoic. Seismic investigations and deep drilling, especially those for oil exploration, indicated that the depression is a narrow asymmetric basin located between two fault zones, the WSG to the west and the Al-Fuluq Fault zone to the east. Three major tectonic periods affected the Azraq basin: the initial phase occurred in the Paleozoic, the next followed in the late Cretaceous and the final one in the Eocene. The Late Cretaceous phase occurred between Cenomanian and Early Maastrichtian time and led to the construction of the Hamzeh structure.

Groundwater is recharged by precipitation at an average volume of $24^{\star} 10^{6} \mathrm{~m}^{3} / \mathrm{a}$, and flows generally toward the center of the WSG. Groundwater is the principal source of freshwater in the basin and is supplied to wells and springs by three principal aquifer systems. The upper aquifer consists of basalt and Umm Rijam Chert Limestone. The middle aquifer consists of the Amman Silicified Limestone. The lower aquifer consists of Lower Cretaceous Kurnub Sandstones. The Basalt-Umm Rijam system is the main aquifer of the Azraq Basin (AlKharabsheh \& Al-Malabeh 2002).

\section{STRATIGRAPHIC SETTING}

Field investigations, deep drilling, seismic survey andGoogle Earth images show that almost a complete stratigraphic column exists in the Wadi Sirhan area from the Precambrian basement up to the Holocene. 


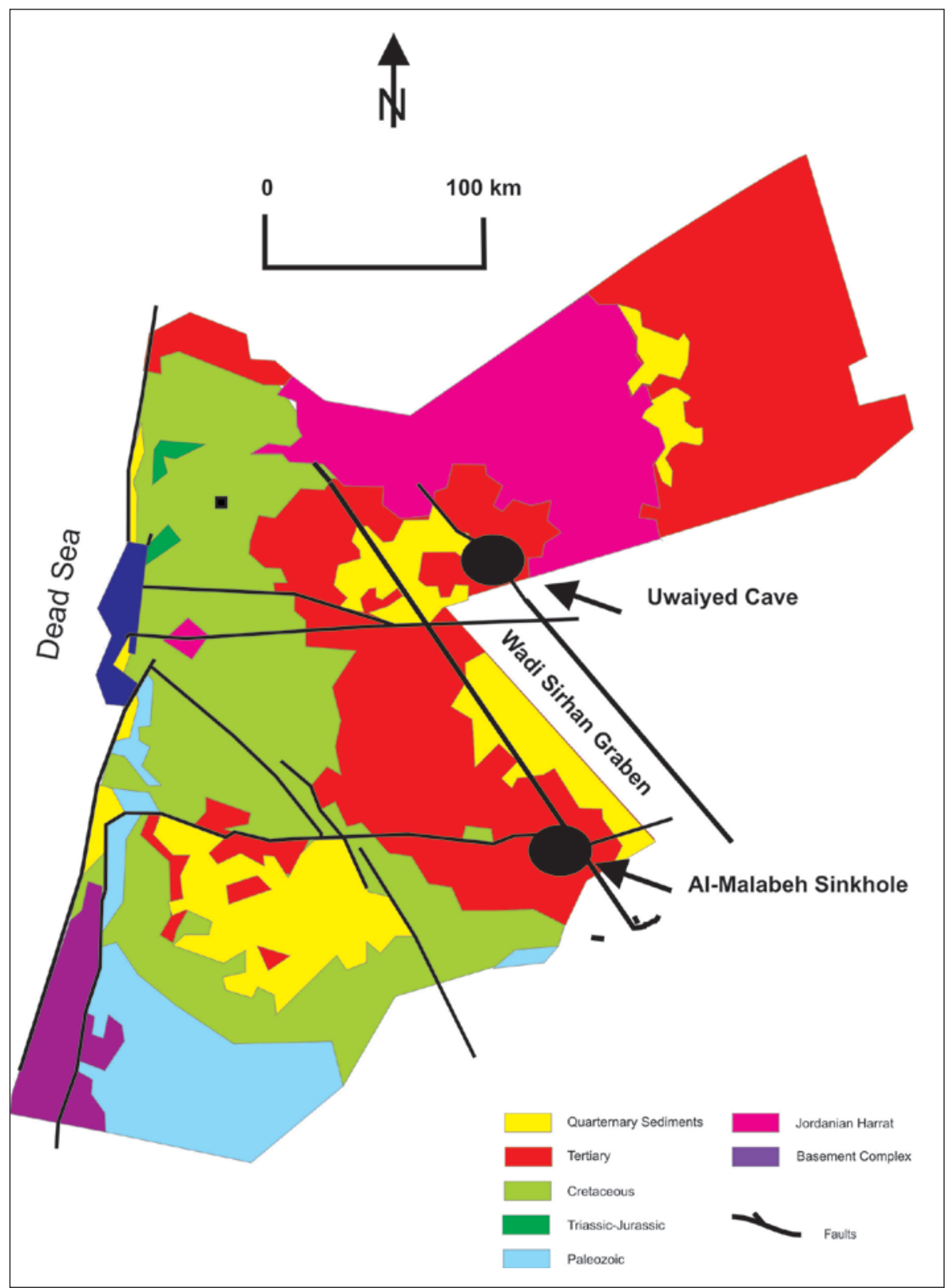

Fig. 1: Sketch map of the geology of Jordan (modified after different resources, e.g., Bender 1974). The main faults and the locations of the two caves discussed in the text are shown. of the intercalation of thick beds of limestone, chalk and varicolored chert (Powell 1989b). Finally, the WSC is dominated by thick beds of chalk intercalated with bands of chert. In this formation the Al-Malabeh Sinkhole occurs (Fig. 1). Many parts of the Sirhan and Azraq area are covered by Pleistocene or younger superficial deposits. Gypsum layers and lenses are recorded in the sediments by drilling and occur mainly in the Upper Cretaceous.

Gypsum occurs in thinner or thicker beds from the Triassic up to the Quaternary. These beds are mainly concentrated in central and southern Jordan (El-Hiyari \& Abed 1985). There are five main localities of gypsum deposits in Jordan (NRA 2012) (Tab. 2). Except for the locally up to $60 \mathrm{~m}$ thick deposits in the Zarka River Basin, gypsum thickness never exceeds $4 \mathrm{~m}$ in the other localities. Most of the beds belong to the Cenomanian-Turonian Fuhays, Hummar, Shu'ayb, and Wadi As-Sir Formations. The over $100 \mathrm{~m}$ thick Upper Jurassic Heeth Anhydrite Formation (e.g., Kempe et al. 2009a) outcropping in central Saudi Arabia does not reach Jordanian territory.

The area of the JabalNaslet Al-Dhirwa volcano, where Uwaiyed Cave is located, is dominated by the oldest volcanics of the Harrat Al-Shaam basalt plateau (known also colloquially as As-Shaam) which is known as the Al-Wisad basalt ( 20-25 Ma).

\section{OIL AND GAS FIELDS IN JORDAN}

The oil and gas fields discovered in Jordan and their productivity and known reserves are hardly worth mentioning at current consumption rates (Abu Jaber et al. 1989; Beydoun et al. 1994; Shinaq 1996). For the pur- 
Tab. 1: Lithostratigraphy of Sirhan area.

\begin{tabular}{l|l|l|l}
\hline Period & Epoch & Formation & Basalt cover \\
\hline \multirow{4}{*}{ Quaternary } & Holocene & Alluvial and Wadi sediments & \multirow{3}{*}{ Basaltic flows of Jordanian Harrat (Al-Shaam). } \\
\cline { 2 - 3 } & Pleistocene & Pleistocene sediments (gravel and sand) & \multirow{3}{*}{ Oligocene-Holocene } \\
\hline & Pliocene & Azraq & \\
\cline { 2 - 3 } & Miocene & Calcareous Sandstone & \\
\cline { 2 - 3 } & Oligocene & Wadi Shallah Chalk & \\
\cline { 2 - 3 } Cretaceous & Eocene & Umm Rijam Chert Limestone & \\
\cline { 2 - 3 } & Paleocene & Muwaquar Chalk Marl & \\
\hline & Maastrichtian & Al Hasa Phosphorite & \\
\cline { 2 - 3 } & Campanian & Amman Silicified Limestone & \\
\cline { 2 - 3 } & Santonian & Wadi Umm Ghudran & \\
\cline { 2 - 3 } & Coniacian & Wadi Al Sir & \\
\cline { 2 - 3 } & Turonian & & \\
\hline
\end{tabular}

Tab. 2: Locations of gypsum deposits in Jordan (modified after NRA 2012).

\begin{tabular}{l|l|l|l}
\hline Area & Formation(s) & Age & Thickness \\
\hline River Zarqa Basin & Abu Ruweis & Triassic & $60 \mathrm{~m}$ \\
\hline $\begin{array}{l}\text { Central and southern Jordan } \\
\text { (Mulih/ Tafila, Wadi Al Hisa, Wadi Al Karak, Wadi Al Mujib) }\end{array}$ & $\begin{array}{l}\text { Fuhays, Hummar, Shu'ayb, } \\
\text { Wadi As Sir }\end{array}$ & Cenomanian-Turonian & $0.2-4 \mathrm{~m}$ \\
\hline Wadi Al-Dahel & Shu'ayb & Cenomanian & $0.5-3.9 \mathrm{~m}$ \\
\hline Jabal Bani-Hamida & Shu'ayb & Cenomanian & $0.8-1.2 \mathrm{~m}$ \\
\hline Azraq & Azraq & Quaternary & $0.25-0.5 \mathrm{~m}$ \\
\hline Lisan & Lisan Marl & Quaternary & $1-1.2 \mathrm{~m}$ \\
\hline
\end{tabular}

pose of oil exploration the NRA subdivided Jordan into ten exploration blocks, each 5,000 to $20,000 \mathrm{~km}^{2}$ in size. Of these only two are presently licensed - National Petroleum Company (NPC) (Risha), Trans Global (Dead Sea). So far about 113 wells have been drilled - 40 of which are in the Risha Gas field. The main period of NRA hydrocarbon exploration was between 1984 and 1995 when 83 wells were drilled. In the last ten years only 14 wells were drilled (eight in Risha). Overall there may be still some potential for smaller fields if more modern technology would be used. 3D surveys have for example only used for Risha and the Dead Sea (NRA 2012).

The only two oil fields productive in Jordan, the Hamza and Wadi Sirhan fields, occur in the eastern desert near to the Saudi Arabian border. The Hamza field is situated in Cretaceous carbonates (Shu'ayb Formation, Cenomanian). 17 wells were drilled in the Hamza field (Hz-1, Hz-12, Hz-14, and Hz-17). Low sulphur oil is produced from four wells and yielded ca. 1 million barrels to date. It currently produces ca. 30 barrels per day (Al-Saideen 2001). The northern and southern sections of the Wadi Sirhan field covering about 11,600 $\mathrm{km}^{2}$ were explored by 14 wells (WS-1 through WS-14) prior to 1991 . The depth of the wells varies from $1,525 \mathrm{~m}$ to $4,580 \mathrm{~m}$. Oil traces were recorded in several wells (e.g., WS-4, known locally as Umm Lahem well) in the Ordo- vician (Dubeideb Formation). The authors visited this well in March, 2008. Oil currently flows out of the damaged well head and is used unprocessed as light oil (Diesel) by the local Bedus.

At present Jordan's gas reserves are 230 billion cubic feet. In NE Jordan, the Risha gas field was discovered in Ordovician clastics close to the Iraq border. It yields 130 million cubic feet gas per day which is supplied to a nearby power station, furnishing merely about $10 \%$ of the total power used by Jordan (Al-Saideen 2001).

The 1980 discovery of from 10 billion to 40 billion tons of shale oil deposits in the Wadi as Sultani area raised Jordanian hopes of greater self-sufficiency, but there were doubts that large-scale exploitation of the deposits would be commercially viable in the near future.

Since 1985 Jordan has attempted to interest Western oil companies in exploring for oil. Amoco, Hunt Petroleum, Petro-Canada, Petrofina of Belgium, and the Japanese National Oil Company were conducting survey work in Jordan in the late 1980s (NRA 2012).

In the Dead Sea asphalt occurs. It floats up from sublacustrine Upper Cretaceous oil seeps and used to be collected and exported since antique times (e.g., Nissenbaum \& Goldberg 1980). 


\section{SINKHOLES ABOVE HYPOGENE CAVES}

\section{UWAIYED CAVE}

The first cave discussed here, Uwaiyed, (Fig. 2), is very small. It is a single, almost circular, chamber $11 \times 9 \mathrm{~m}$ wide and less than $4 \mathrm{~m}$ high at its apex (Fig. 3). The entrance is through an artificially enlarged square pit to the NW. The cave has a slightly sloping floor, covered with breakdown blocks and stalagmites from pigeon guano. The roof of the cave is lava that is highly weathered and shows veins of hydrothermally (?) deposited chalcedony. The cave occurs half way up a small, highly eroded lava hill that appears to be a remnant of a former strato-volcano dominated by thick lava strata intercalated by scoria. It is locally known as Naslet Al-Dhirwa (Al-Malabeh 2007; Kempe et al. 2009b). Due to the breakdown character of the cave and its circular shape the only explanation for its existence is, that it formed by upward stoping above a much deeper collapsed cave. This cave would have formed in the underlying limestones and the fact that the cave is now a lava cave is purely due to incident.

\section{THE BEER AL-MALABEH SINKHOLE}

The second cave is much larger. It was discovered by the first author in 1999 during his eco- and geo-tourism field trips in the Jordanian Badia (Al-Malabeh 2000, 2006) and explored and surveyed by the second author and Dr. Horst-Volker Henschel on May $11^{\text {th }} 2006$ (Fig. 4). The area of the sinkhole is only sparsely inhabited seasonally by Bedus. For them the area of the sinkhole is the site of a meteorite impact. Smaller sinkholes are observed throughout the area from Al-Thlaythowat Mountains in the northern parts of the Sirhan area to Beer Al-Malabeh in the south. These holes vary in dimension from one meter up to several meters in diameter. But none opens up into an underlying cavity.

The Al-Malabeh sinkhole (Fig. 5) is entered through a window of about $9 \times 5 \mathrm{~m}$ in size that leads into a bellshaped large chamber occupied by a large pile of breakdown at its centre. The main axis of the bell is directed
NW-SE and measures $38 \mathrm{~m}$, while the minor axis measures $26 \mathrm{~m}$. The apex of the central pile is at $11.5 \mathrm{~m}$ below the entrance and the deepest point reached is the NW corner at $22.4 \mathrm{~m}$ below the entrance. Access is by rope or cable ladder by a $16 \mathrm{~m}$ long drop (Fig. 6).

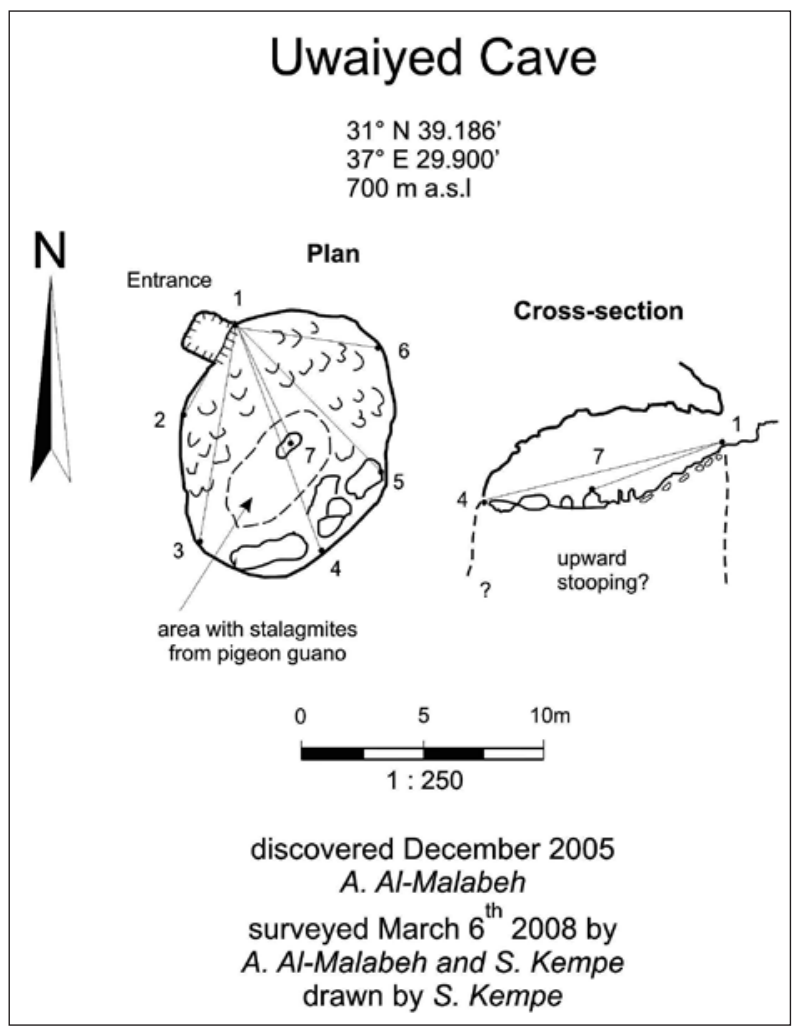

Fig. 2: Map of Uwaiyed Cave.

The walls of the cavity are composed of thinly bedded Eocene limestone, interbedded with marls. Pigeons use the cave as roosts and have left large deposits of guano. Bedus have discarded over 30 oil barrels in the cave and a broken ladder constructed of water

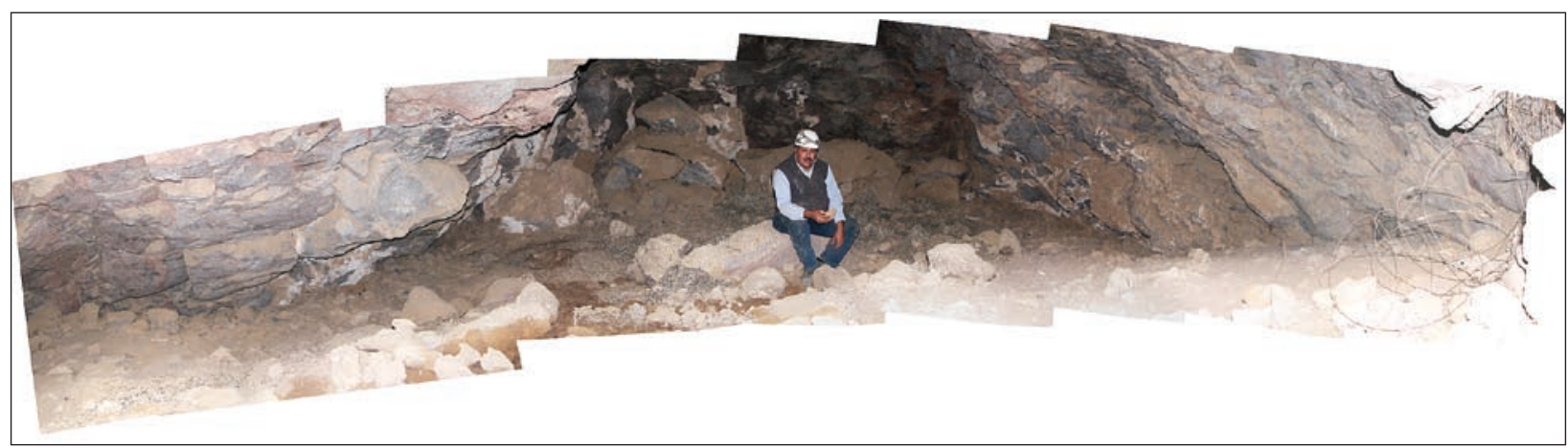

Fig. 3: Panorama view of Uwaiyed Cave from the entrance (Photo: S. Kempe; Kempe et al. 2009b). 


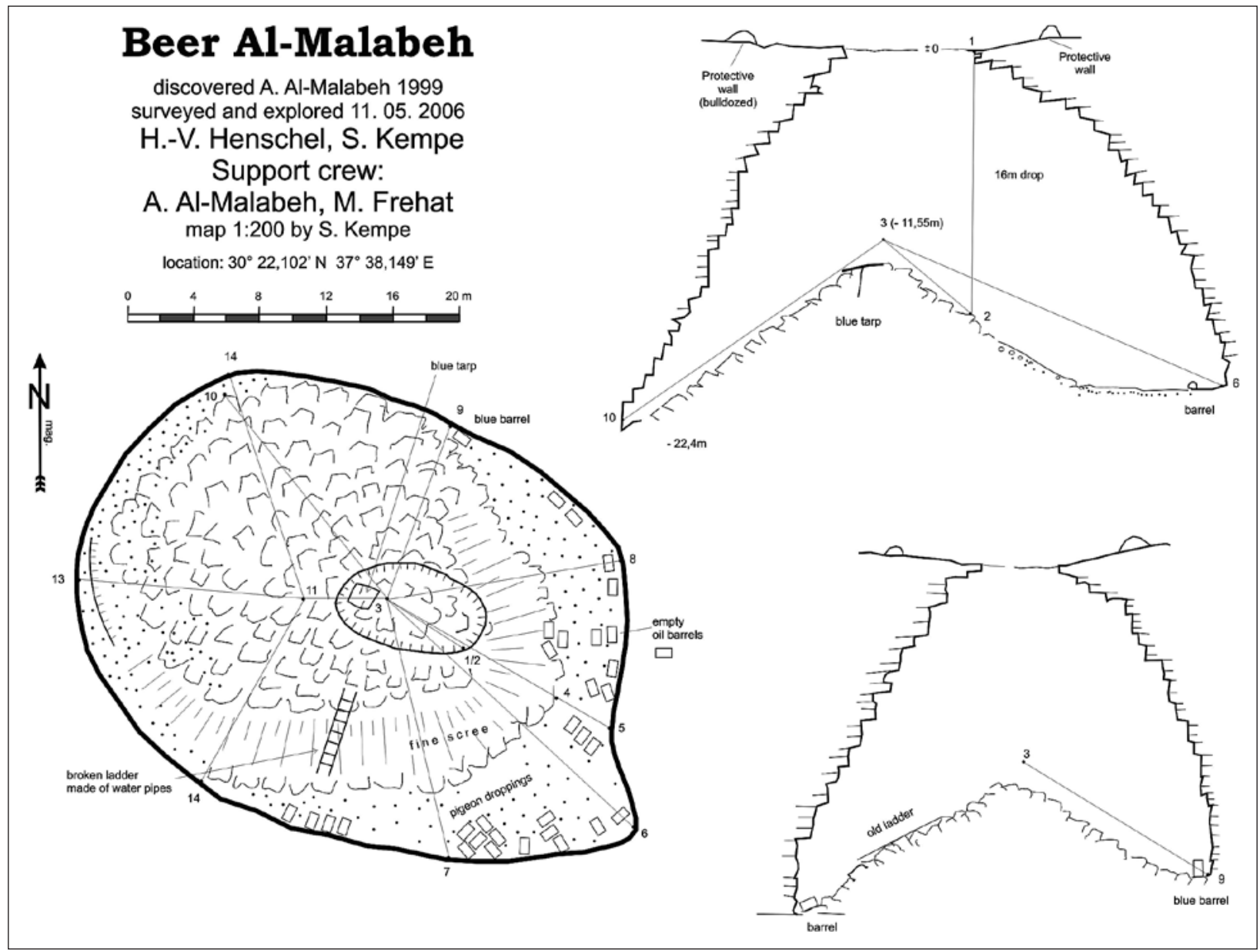

Fig. 4: Map and cross-sections of Al-Malabeh Sinkhole.

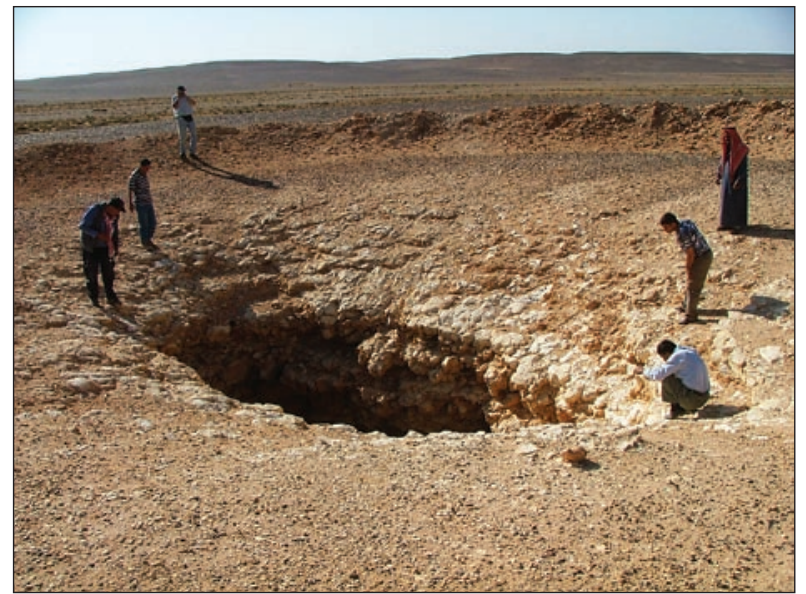

Fig. 5: View of the entrance of the Al-Malabeh Sinkhole. Note the recently constructed protective earth wall surrounding the entrance (Photo: S. Kempe; Kempe et al. 2009b). pipes and a blue tarp are witnesses to earlier descent attempts.

The cave is clearly a natural collapse feature slowly stoping upward. It is just in the stadium of having opened up to the surface recently. The explanation that this cavity is a Nabtaean cistern (Nabataea.net 2003) is entirely unfounded because (i) there is no waste pile of the rocks removed (amounting to c. $8000 \mathrm{~m}^{3}$ of solid and $>10,000 \mathrm{~m}^{3}$ of loose rock), (ii) there is no channel or water course approaching the inward sloping cave entrance, (iii) the opening is not in the deepest part of a valley but rather near to the water divide in between two wadis, (iv) the thinly bedded rock would not hold any water for any time and no artificial lining (such as plaster) is present in the cave and (v) there are no other above ground archaeological remains that should be associated with such an exceptionally large cistern (protective walls, foundations of houses, pens for sheep or camels; remains of stone tools, bones and pottery). 


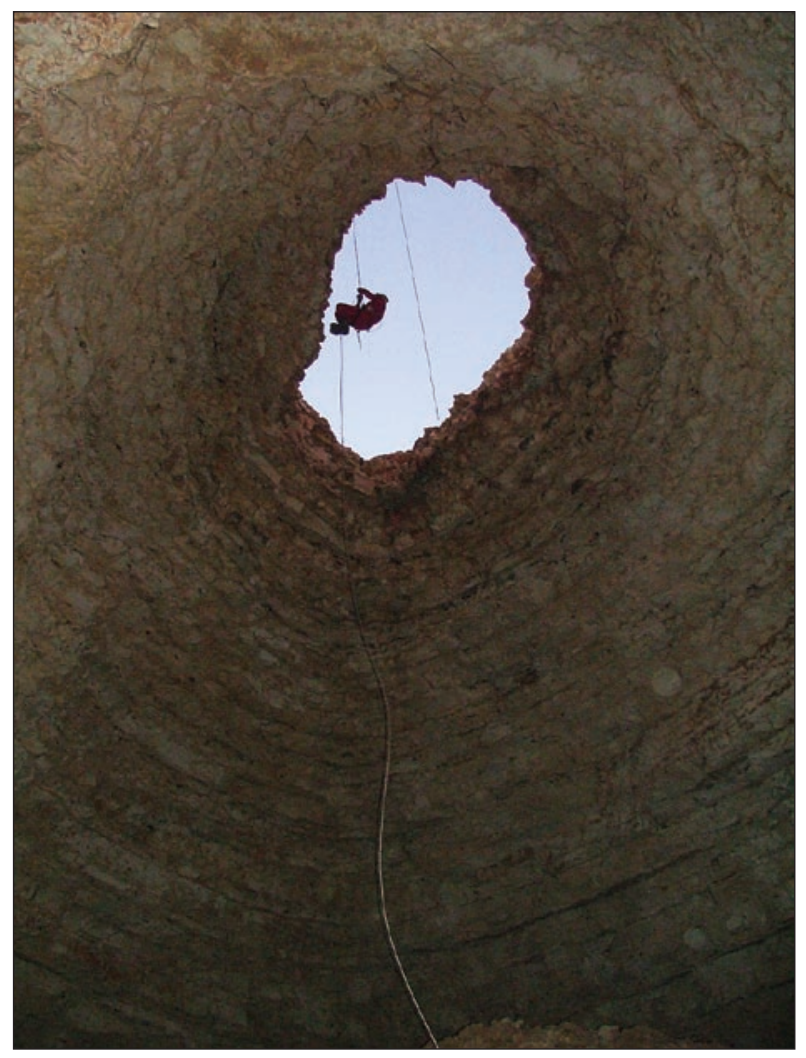

Fig. 6: View from the bottom up to the window of Al-Malabeh Sinkhole (Photo: S. Kempe).

\section{CONCLUSIONS}

The occurrence of a collapse structure in a limestone area otherwise devoid of known caves suggests the existence of cavities with a very large volume at or below the water table. Such collapses occur for example in Germany over dissolving salt deposits. The "Wolkenbrüche" near Trendelburg, Hessen, are such structures. Two sinkholes, one $150 \mathrm{~m}$ wide and $47 \mathrm{~m}$ deep, formed when at a depth of 1,300 m salt caves in Upper Permian deposits collapsed, creating a breccia pipe through the overlying Lower Triassic sandstone (Buntsandstein) and corresponding sinkholes at the surface. Such breccia pipes are sometimes more resistant to erosion than the surrounding rocks. In the Delaware Basin, western Texas/southeastern New Mexico, several such pipes composed of limestone have formed in anhydrite (e.g., Anderson \& Kirkland 1980). The anhydrite is more easily removed than the limestone composing the pipes leaving them as hills.

A lava cave similar to Uwaiyed Cave, albeit much larger, was discovered in 1990 by basalt quarrying in Germany: the $52 \mathrm{~m}$ long Basalthöhle Ortenberg (Rühl et al. 1991). It consisted of a single large breakdownshaped hall within the columnar basalt that must have formed but upward stoping of a collapsed cave in the underlying Zechstein evaporites.

Both of the caves discussed here have - geologically speaking - opened up to the surface relatively recently. They will eventually be transformed into vertically walled sinkholes and then into crater-like depressions thus forming "Erdfälle" or "breakdown dolines" (for terms see Kempe \& Rosendahl 2000).

Thus, these sinkholes are only the weak surface traces of a cavity-forming process at great depth. Several options exist to explain these apparently existing hypogene cavities. In comparison with the referenced German examples one could first think about salt dissolution. However, the oil wells did not meet any salt deposits. The second possibility is forming a cave due to gypsum dissolution. Examples would be the Saudi Arabian Layla Lakes sinkholes and the Ain Heeth Cave (Kempe \& Dirks 2008; Kempe et al. 2009a). Tab. 2, however, shows that only marginally thick gypsum layers occur within the stratigraphic column underlying the two cave sites. With layers at most $4 \mathrm{~m}$ thick is does not seem likely that a cavity large enough to progress upward to the surface 
could be formed. Nevertheless, this possibility cannot be excluded entirely.

Thus, we must look at processes that allow limestone dissolution away from general epigenetic karst aquifers. Plumes of rising gases could play such a role. Two possibilities exist: The cavity formed either by $\mathrm{CO}_{2}$ rising from below the limestone formations, or it formed by the oxidation of rising $\mathrm{CH}_{4}$ or $\mathrm{H}_{2} \mathrm{~S}$. In the first case, a cavity would form at the base of the limestone stratigraphic column, possibly at the top of the Lower Cretaceous Sandstone. The source of such $\mathrm{CO}_{2}$ could be volcanic. However, in the area of the Al-Malabeh Sinkhole, no volcanic activity ever existed. Thus, rising $\mathrm{CH}_{4}$ and $\mathrm{H}_{2} \mathrm{~S}$ seem to be the most promising gases to cause speleogenesis in this case. There are plenty of candidate strata to generate these gases: the site is underlain by several oilshale formations and possibly small oil fields in the Ordovician (Hamza Field). $\mathrm{CH}_{4}$ or $\mathrm{H}_{2} \mathrm{~S}$ generated there could have risen along faults, such as the small fault running across the Al-Malabeh Sinkhole. Once the gases arrive at the local water table, which is within the limestone strata in that area at about a depth of $70 \mathrm{~m}$, they can be oxidized bacterially by oxygen carried down by percolating water. The oxidation process (see Equations 5 and 6) produces the acids that allow alocalized cavity to form. Thus the sinkholes and their hypogene cavities could be taken as possible signs of oil field degassing.

\section{ACKNOWLEDGEMENTS}

The authors are indebted to many local Bedus who helped in locating caves in the desert and provided first aid with blown tires and overnight shelter. We also thank Dr. Horst-Volker Henschel and geologist Mahmoud Frehatin helping with the exploration and survey of Al-Malabeh Sinkhole. We thank the Hashemite University and the Badia Research Center for providing transportation and accommodation. The first author was supported by grants from the Deutsche Akademische Austauschdienst (DAAD) and the Deutsche Forschungsgemeinschaft (DFG).

\section{REFERENCES}

Abu Ghazleh, S., Hartmann, J., Jansen, N., \& S. Kempe, 2009: Water input requirements of the rapidly shrinking Dead Sea.- Naturwissenschaften, 96, 5, 637-643.

Abu Jaber, N., Kimberly, M. \& V. Cavaroc, 1989: Mesozoic-Palaeogene basin development within the eastern Mediterranean borderland.- J. Petroleum Geol., $12,4,419-436$.

Al-Kharabsheh, A. \& A. Al-Malabeh, 2002: Water harvesting in Wadi Al-Maghyer, Azraq Basin-Jordan and its environmental impacts.- Proc. Congress in Urban Developments in Arid Region \& Associated Problems, 3, 97-106.

Al-Malabeh, A., 1994: Geochemistry of two volcanic cones from the intra-continental plateau basalt of Harra El-Jabban, NE-Jordan.- In: Basaltic Rocks of Various Tectonic Settings, Spec. Issue Geochem. J., 28, pp. 542-558, Japan.
Al-Malabeh, A., 2000: Natural phenomena and outcrops in Jordan as environmental geotopes.- In: Rimawi, R. et al. (eds.) Proc. $1^{\text {st }}$ Jordan Environ. Conf. of Jordanian Geologists Association, $5^{\text {th }}-7^{\text {th }}$ November 2000, Amman, Jordan. Jordanian Geologists Association, 156-159, Amman.

Al-Malabeh, A., 2006: In the day when the surface of the earth collapses down, Beer Al-Malabeh.- Culture Mag., Hashemite Uni., 2, 23-25.

Al-Malabeh, A., 2007: Discovery of seven new lava caves in the basaltic of Jordanian Harrat.- In: Al-Malabeh, A. \& K. Momani (eds.) Proc. $6^{\text {th }}$ Intern. Symp. on Eastern Mediterranean Geology and the $9^{\text {th }}$ Intern. Conf. of Jordan Geologists Association, $2^{\text {nd }}-5^{\text {th }}$ April 2007, Amman, Jordan. Jordanian Geologists Association, 170, Amman. 
Al-Malabeh, A., Frehat, M., Henschel, H.-V. \& S. Kempe, 2006: Al-Fahda Cave (Jordan): the longest lava cave yet reported from the Arabian Plate.- Assoc. for Mexican Cave Studies, Bull. 19 and Socieded Mexicana de Exploraciones Subterraneas, Bol. 7, 201-208.

Al-Malabeh, A., Kempe, S., Frehat, M. \& H.-V. Henschel, 2007: Geo-conservation of the newly discovered Kufranja Cave, N-Jordan, a potential natural heritage site.- In: Al-Malabeh, A. \& K. Momani (eds.) Proc. $6^{\text {th }}$ Intern. Symp. on Eastern Mediterranean Geology and the $9^{\text {th }}$ Intern. Conf. of Jordanian Geologists Association, $2^{\text {nd }}-5^{\text {th }}$ April 2007, Amman, Jordan. Jordanian Geologists Association, 174, Amman.

Al-Saideen, M., 2001: Petroleum exploration in the Azraq Basin.- Unpubl. Rep., National Petroleum Company (NPC), pp. 25, Amman, Jordan.

Anderson, R.Y. \& D.W. Kirkland, 1980: Dissolution of salt deposits by brine density flow.- Geology, 8, 66-69.

Arkin, Y. \& A. Gilat, 2000: Dead Sea sinkholes-an everdeveloping hazard.- Environ. Geol., 39, 7, 711-722.

Barazangi, M., 1983: A summary of the seismotectonics of the Arab region.- In: Cidlinsky, K. \& B. Rouhban (eds.) Assessment and Mitigation of Earthquake Risk in the Arab Region. UNESCO, pp. 43-58, Paris, France.

Bender, F., 1974: Geology of Jordan.- Bornträger, pp. 196, Berlin, Stuttgart.

Beydou, Z., Fytyan, A. \& A. Jawzi, 1994: Jordan revisited: Hydrocarbon habitat and potential.- J. Petroleum Geol., 17, 2, 177-194.

Bögli, A., 1964: Mischungskorrosion: Ein Beitrag zum Verkarstungsproblem.- Erdkunde, 18, 83-92.

Closson, D., 2005: Co-Occurrence of the Geo-Hazards Induced by the Dead Sea Level Lowering and the Geological Setting; Lisan Peninsula, Lynch Strait, Ghor Al Haditha - Jordan.- PhD Thesis. Liege Univ. Belgium, pp. 143.

Dreybrodt, W., 2008: Von der Kluft zum Urkanal, Chemie und Physik der Höhlenentstehung.- In: Kempe, S. \& W. Rosendahl (eds.) Höhlen, verborgene Welten. Wissenschaftliche Buchgesellschaft, pp. 39-53, Darmstadt.

Dublyansky, Y.V., 2000: Hydrothermal speleogenesis - its settings and peculiar features.- In: Klimchouk, A.B., Ford, D.C., Palmer, A. N. \& W. Dreybrodt (eds.) Speleogenesis: Evolution of Karst Aquifers. National Speleological Society, pp. 292-297, Huntsville, Alabama.

El-Hiyari, M., 1985: The Geology of the Jabal Al-Mutarammil area.- Map Div. Geol. Dir. Nat. Resources Authority (NRA), Bull. 1, pp. 36, Amman.
El-Hiyari, M. \& A. Abed, 1985: Distribution and geology of gypsum horizons in west-central Jordan.- In: Abed, A. et al. (eds.) Proc. $2^{\text {nd }}$ Jordanian Geological Conference, $22^{\text {nd }}-24^{\text {th }}$ April 1985, Amman, Jordan. Jordanian Geologists Association, 361-419, Amman.

Gary, M. O. \& J. M. Sharp, 2006: Vulcanogenic karstification of Sistema Zacatón, Mexico.- Geolog. Soc. Amer. Spec. Pap., 404, 79-89.

Gregory, R., Coleman, R. \& G. Brown, 1982: Cenozoic volcanic rocks of Saudi Arabia: evidence from the continent for a two-stage opening of the Red Sea.Geol. Soc. Am. Annual meeting Abstracts with Programs, 14, 7, p. 502.

Hill, C.A., 2000: Sulfuric acid, hypogene karst in the Guadalupe Mountains of New Mexico and West Texas, U.S.A.- In: Klimchouk, A.B., Ford, D.C., Palmer, A.N. \& W. Dreybrodt (eds.) Speleogenesis, Evolution of Karst Aquifers. National Speleological Society, pp. 309-316, Huntsville, Alabama.

Kazmin, V.G., 2002: The late Paleozoic to Cainozoic intraplate deformation in North Arabia: a response to plate boundary-forces.- European Geosciences Union (EGU) Stephan Mueller Spec. Publ. Ser., 2, $123-138$

Kempe, S., 1975: Siderite weathering, a non-biogenetic source of $\mathrm{CO}_{2}$ (illustrated by the Iberg/Harz/Fed. Rep. of Germany).- Ann. de Spéléologie, 30, 4, 703704.

Kempe, S., 1996a: Gypsum karst of Germany.- In: Klimchouk, A., Lowe, D., Cooper, A. \& U. Sauro (eds.) Gypsum Karst of the World. Intern. J. Speleol. Spec. Issue, 25, 3-4., pp. 209-224.

Kempe, S., 1996b: Primäre und sekundäre Lösungskapazität.- Arge Höhle u. Karst Grabenstetten, Jahresheft 1995, anlässlich der 36. Jahrestagung des Verbandes der deutschen Höhlen- und Karstforscher in Blaubeuren, 1996, 13-17.

Kempe, S., 1996c: Steter Tropfen höhlt den Stein? Wie Höhlen wirklich entstehen.- In: Rosendahl, W. \& E. - B. Krause (eds.) Im Reich der Dunkelheit, Höhlen und Höhlenforschung in Deutschland. Edition Archaea, pp. 22-32, Gelsenkirchen.

Kempe, S., 2002: Lavaröhren (Pyroducts) auf Hawai'i und ihre Genese.- In: Rosendahl, W. \& A. Hoppe (eds.) Angewandte Geowissenschaften in Darmstadt. Schriftenreihe der deutschen Geologischen Gesellschaft, 15, 109-127.

Kempe, S., 2008: Vom Urkanal zur unterirdischen Kathedrale, Höhlenformen und ihre Entstehung.- In: Kempe, S. \& W. Rosendahl (eds.) Höhlen: Verborgene Welten, Wissenschaftliche Buchgesellschaft, pp. 54-64, Darmstadt. 
Kempe, S., 2009: Siderite weathering as a reaction causing hypogene speleogenesis: the example of the Iberg/Harz/Germany.- In: Klimchouk, A. \& D. Ford (eds.) Hypogene Speleogenesis and Karst Hydrogeology of Artesian Basins. Ukrainian Inst. of Speleology and Karstology, Spec. Pap., 1, pp. 59-60, Simferopol.

Kempe, S. \& H. Dirks, 2008: Layla Lakes, Saudi Arabia: The world-wide largest lacustrine gypsum tufas.Acta carsologica, 37, 1, 7-14.

Kempe, S. \& W. Rosendahl, 2000: Vom „Erdfall“ zur „Doline“: Die eher zufällige Einführung eines „Fachbegriffes“ durch Morlot und Schmidl in den Jahren 1848 bis 1854.- Mitt. Verb. Dt. Höhlen- u. Karstforscher (Pfeffer Festschrift), 2000, 1/2, 49-55.

Kempe, S., Al-Malabeh, A., Al-Shreideh, A. \& H.-V. Henschel, 2006a: Al-Daher Cave (Bergish), Jordan, the first extensive Jordanian limestone cave: A convective Carlsbad-type cave?- J. Cave and Karst Studies, $68,3,107-114$.

Kempe, S., Al-Malabeh, A., Henschel, H.-V. \& M. Frehat, 2006b: State of lava cave research in Jordan.- Assoc. for Mexican Cave Studies, Bull. 19 and Socieded Mexicana de Exploraciones Subterraneas, Bol. 7, pp. 209-218.

Kempe, S., Dirks, H. \& I. Bauer, 2009a: Hypogene karstification in Saudi Arabia (Layla Lake Sinkholes, Ain Heeth Cave).- In: Klimchouk, A. \& D. Ford (eds.) Hypogene Speleogenesis and Karst Hydrogeology of Artesian Basins, Ukrainian Institute of Speleology and Karstology, Spec. Pap., 1, pp. 247-251, Simferopol.

Kempe, S., Al-Malabeh, A. \& H. - V. Henschel, 2009b: Hypogene karstification in Jordan (Al-Daher Cave, Uwaiyed Cave, Beer Al-Malabeh Sinkhole).- In: Klimchouk, A. \& D. Ford (eds.) Hypogene Speleogenesis and Karst Hydrogeology of Artesian Basins, Ukrainian Inst. of Speleology and Karstology, Spec. Pap., 1, pp. 253-255, Simferopol.

Klimchouk, A., 2007: Hypogene Speleogenesis: Hydrogeological and Morphogenetic Perspective.- National Cave and Karst Research Institute, Spec. Pap., 1, pp. 106.

Klimchouk, A.B., Ford, D.C., Palmer, A.N. \& W. Dreybrodt (eds.), 2000: Speleogenesis: Evolution of Karst Aquifers.- National Speleological Society, pp. 527, Huntsville, Alabama.
McKenzie, D., Davies, D. \& P. Molnar, 1970: Plate tectonics of the Red Sea and East Africa.- Nature, 226, 243-248.

Nabatea.net, 2003: A New Proposed Trade Route [Online] Available from: http://nabataea.net/nroute. html [Accessed 12.02.2012].

Natural Resources Authority (NRA), 2012: Minerals \& Rock [Online] Available from: http://www.nra.gov. jo/index.php?option=com_content\&task=view\&id $=31$ \&Itemid $=62$ [Accessed 12.02.2012].

Nissenbaum, A. \& M. Goldberg, 1980: Asphalts, heavy oils, ozocerite and gases in the Dead Sea basin.- Organic Geochemistry, 2, 167-180.

Palmer, A.N., 2008: Cave Geology.- Cave Books, pp. 454, Dayton, Ohio.

Palmer, A.N. \& M. V. Palmer, 2000: Hydrochemical interpretation of cave patterns in the Guadalupe Mountains, New Mexico.- J. Cave and Karst Studies, 62, 2, 91-108.

Powell, J.H., 1989a: Stratigraphy and sedimentation of the Phanerozoic rocks in Central and South Jordan: Part A, Ram and Khrein Groups.- Natural Resources Authority: Geol. Dir. Map. Div. Bull., 11a, 72.

Powell, J.H., 1989b: Stratigraphy and sedimentation of the Phanerozoic rocks in Central and South Jordan: Kurnub, Ajlun and Belqa Groups.- Natural Resources Authority: Geol. Dir. Map. Div. Bull. 11b, 130.

Rühl, B., Schreiber, B. \& G. Stein, 1991: Basalthöhle im Steinbruch Ortenberg-Bergheim (Wetteraukreis, Hessen) entdeckt und einstweilig sichergestellt.Mitt. Verband Dt. Höhlen- und Karstforscher, 37, $1,18-19$.

Shinaq, R., 1996: Subsurface Triassic sediments in Jordan: Stratigraphic and depositional characteristics, and hydrocarbon potential.- J. Petroleum Geol., 19, $1,57-76$.

Wigley, T.M., 1973: Chemical evolution of the system calcite-gypsum-water.- Canadian J. Earth Sci., 10, 306-315.

Wigley, T.M. \& L.N. Plummer, 1976: Mixing of carbonate waters.- Geochimica et Cosmochimica Acta, 40, 989-995. 